\title{
Evaluation of Ghana's 2007 Educational Policy: Effects on Education in the Upper West Region
}

\author{
Amina Jangu Alhassan \\ Institute for Educational Planning and Administration (IEPA), University of Cape Coast, Ghana
}

Received June 17, 2020; Revised July 20, 2020; Accepted August 25, 2020

\section{Cite This Paper in the following Citation Styles}

(a): [1] Amina Jangu Alhassan, "Evaluation of Ghana's 2007 Educational Policy: Effects on Education in the Upper West Region," Universal Journal of Educational Research, Vol. 8, No. 9, pp. 4242-4260, 2020. DOI: 10.13189/ujer.2020.080951.

(b): Amina Jangu Alhassan (2020). Evaluation of Ghana's 2007 Educational Policy: Effects on Education in the Upper West Region. Universal Journal of Educational Research, 8(9), 4242-4260. DOI: 10.13189/ujer.2020.080951.

Copyright $(2020$ by authors, all rights reserved. Authors agree that this article remains permanently open access under the terms of the Creative Commons Attribution License 4.0 International License

\begin{abstract}
The Ghana 2007 educational policy aims to improve performance in the education sector. The current study is interested in investigating the provisions made for free and compulsory education in the Ghana 2007 educational policy regarding the Wa Municipality. The researcher believes that there is a gap between the provisions made and the extent to which the policy provisions has impacted on free and compulsory education in the Wa Municipality. Four research questions guided the research. A sample size of 350 members consisting of stakeholders of education in the Municipality was selected using purposive and simple random sampling. A questionnaire and an interview guide were designed and used to collect data over a period of eight weeks. Qualitative analysis was employed to analyze the data with an emphasis on thematic analysis and a little descriptive statistic. The findings showed that the provisions are implemented resulting in increased enrolment figures but not without significant challenges that are threatening the sustenance of the success so far achieved in the Municipality. Thus, members demonstrated that education at the basic level is free but not compulsory in the Wa Municipality.
\end{abstract}

Keywords Policy, Education, Enrollment, Free-compulsory, Implementation

\section{Introduction}

An educational system must promote national cohesion, and the purpose of a national policy on education is to foster this coherence (Olatunji, 2015). A government usually formulates an educational policy and over the years, politics has found its way into educational policies in many countries (Little, 2010) of which Ghana is no exception. The phenomenon is made possible because, policies governing the operation of schools are left in the hands of politicians (Braimah, Mbowura, \& Seidu, 2014). Scholars like Braimah, Mbowura and Seidu (2014) argued that decisions on Ghana's educational system are not based on what the Ghanaian populace need but rather on what the political party in power says. Again, Thomas (2012) noted that most of the educational policies crafted by politicians do not take into consideration the level of expertise required to generate the plans. It is also an open fact and supported by literature that some Ghanaian children are attending schools that lack infrastructure and teachers, to prepare them to fit well in society (Inkoom, 2012). Ghana's education system is facing an unacceptably high dropout rate (UNICEF, 2012). At the primary level enrolment figures are high. By the time students reach secondary school enrollment figures have dropped drastically to about $10 \%$ of the numbers that enrolled at the primary level (Anamoah-Mensah, 2002; UNICEF, 2012). In 2007, about one million children were not in school while about $20 \%$ of school-going age children drop out of school before they reach high school (Nordensvard, 2013). Considering this, Nordensvard (2013) described Ghana as one of the negative examples of countries that cannot implement a universal educational policy. Nordensvard (2013) argues that Ghana is plagued with some divisions that have 
impacted on the way education is constructed in the country, and this drifts down to the regional levels as well. Gough and Woods (2006) blame the situation on over-reliance on powerful external players, aid and remittances. To address these challenges Ghana needs to examine the quality of its educational policies and draw lessons from other nation's approach to educational policy implementation.

\subsection{Statement of the Problem}

There is an alarming poor attendance and absenteeism in schools in Ghana (Eyiah, 2013) and the Wa Municipality is no exception. The situation has influenced many young girls and boys to migrate to urban cities for non-existing jobs. It is the hope of the researcher that the current research will provide empirical evidence on the state of the provisions made for free and compulsory education in Ghana's 2007 educational policy in the Wa Municipality. Therefore, the researcher aims to evaluate the opinion of stakeholders of education on how Ghana's 2007 educational policy has affected free and compulsory education in the Wa Municipality of the Upper West Region in Ghana.

\subsection{Purpose of the Study}

The purpose of the study is to evaluate Ghana's 2007 educational policy with specific reference to the provisions made for the FCUBE in the Wa Municipality. The intention is to determine how well the provisions made for free and compulsory education have been implemented to increase enrollment figures in the Wa Municipality. The purpose of the study is also to suggest strategies for implementing educational policies in the region to achieve maximum benefits. Additionally, the purpose of the study is to add information based on empirical evidence about the progress of enrollment policies and reforms for the education sector in the Wa Municipality.

\subsection{Research Questions}

The following four research questions were set to guide the collection of data for the study:

1. How Relevant are the provisions made for the FCUBE in Ghana's 2007 educational policy to the people in the Wa Municipality?

2. Will you say the implementation of Ghana's 2007 educational policy has brought free and compulsory education to the Wa Municipality?

3. What factors affect the implementation of Ghana's 2007 educational policy regarding Free and Compulsory education in the Wa Municipality?

4. What strategies can enhance maximum implementation of free and compulsory education in the Wa Municipality?

\subsection{Significance of the Study}

The research is significant because the current gap suggests there is not enough empirical information on the extent to which Ghana's 2007 educational policy has been implemented in the Wa Municipal concerning enrollment per the free and compulsory education. The research is again, significant because Ghana's 2007 educational policy plays a critical and central role in the assessment of education in Ghana. Therefore, it is necessary to review the policy implementation in time to find out how people have benefited from the provisions. The research is again, significant because it will enhance decision-making that will promote quality education among the people of the Wa Municipality through suggestions and recommendations. A strategic plan will be proposed to enhance the successful implementation of educational policies in the Municipality.

\subsection{Theoretical Framework}

A theory is a kind of generalized thinking or explanation of how nature works. A theory can be prescriptive by postulating what ought to be, or by providing goals, and standards to serve as a direction (Anfara \& Mertz, 2006). The theoretical framework guiding the study is grounded in the fundamental tenets of the principles of social change by Tyack and Cuban (1995). The principles of social change are embedded in Tyack and Cuban (1995) views about the assumptions and purposes of public education. They outlined that for education to achieve its purpose the people who champion the cause must understand the political dimensions of school reforms and some of the dimensions are to involve teachers in the formulation process and not just for implementation alone. Also, people must understand that the process of change is complex and requires a lot of commitment from all stakeholders of education and that people must learn from their past. The current research will benefit from the ideas of Tyack and Cuban (1995) by looking out for how we can draw a healthy balance between educational policy formulation and their achievements levels, especially at the $\mathrm{Wa}$ Municipality.

\subsection{Delimitations/Limitations}

The only delimitation facing the current research is the restriction of the study to only basic schools in the Wa Municipality. The choice of the basic schools is informed by the area the researcher is interested in surveying and it falls under the jurisdiction of basic schools. The other area of delimitation was the choice of the Wa Municipality. The idea of selecting a single unit of communities in the region goes in line with research principles (Creswell, 2013) except that the findings will not be generalized due to the non-representativeness of the sample population. 


\section{Literature Review}

The review is organized under three main topics that are of relevance to the research questions.

\subsection{Major Highlights of Ghana's 2007 Policy on Education}

The Ghana 2007 educational policy made provisions for some adjustments in the Ghana education system to ensure success in the attainment of educational goals (UNESCO, 2007). They include, but not limited to restructuring Universal Basic Education for eleven years. Formally, primary education was ten years with seven years of secondary education in all making it seventeen years of pre-university education (UNESCO, 2007; Eyiah, 2013). The current proposed eleven years are made up to two years of Kindergarten education; six years of primary school education, and three years of Junior High School education. While Senior High School takes three years in all making it fourteen years of pre-university education (Eyiah, 2013). The policy also proposed Ghanaian language and English as the medium of instruction in Kindergarten and the first three years of primary schooling (UNESCO, 2007). Thus, teachers were to use the local language of the community a school is located to teach Kindergarten and lower primary. The policy again indicated that the primary level curriculum should emphasize creative arts, numeracy, and the development of problem-solving skills. The suggestion was a re-emphasis of the fact that children learn best-doing activities, and hence, it directs the teacher's focus on child-centred learning activities. The 2007 policy expected pupils to choose secondary education, according to the streams available in the Ghanaian educational system. The different streams are science, general arts, home economics, agriculture education, and technical education.

Another provision of the 2007 policy is Free Compulsory Universal Basic Education (FCUBE). The FCUBE presented three dimensions for analysis. The first is the free aspect of primary education. The second is the compulsory element, and the third is the universal aspect. The policy is expected to implement free education for all Ghanaians of school-going age (UNESCO, 2007). Pupils who require special attention were not left out of the provisions of Ghana's 2007 educational policy. It was proposed that special education will be improved at all levels. The system also allowed the private sector to continue to participate in the provision of education to the citizenry (Ministry of Education, 2013). The efficiency and effectiveness of every educational system lie in its ability to produce the right quality of people, individuals who can manage and utilize resources to increase output. Hence, teacher education is given a lot of priority in the 2007 educational policy. To better regulate and coordinate teacher training, the Ghana 2007 educational policy recommended the establishment of a National Teaching Council (NTC). The council was to spearhead the activities at teacher training colleges and make recommendations for better training programs.

\subsection{Post-Colonial Educational Reforms and Policies in Ghana}

Aside from the Ghana 2007 educational policy, there have been others, starting with the 1951 educational policy (Kadingdi, 2006; Staff, 2016). The policy also known as the Accelerated Development Plan for Education made some significant contributions to the development of education in the country (Kadingdi, 2006). The implementation of the reform experienced an increase in access to education due to the removal of tuition fees in public primary schools that was between 15 shillings and 30 shillings annually. But parents still had to pay for books except for an exemption in Northern Ghana (Ministry of Local Government and Rural Development, 2006). In addition to the removal of tuition fees, schools that were initially not on the budget of the government were brought on board (Inkoom, 2012 \& Godwyll, 2003). Government expenditure on education increased and with the limited resources on the part of government quality was compromised (Adamu-Issah, Elden, Forson, \& Schrofer, 2007). After the 1951 education policy, the Education Act of 1961was introduced.

The Art of 1961 re-affirm some of the provisions of the 1951 educational policy such as the abolition of tuition fees, and the existence of private institutions. There were other new developments such as making education compulsory for all children aged between five and sixteen. Again, parents whose children were truant were to be fined. More so, a shift system was put in place to address the significant numbers of students pending the construction of more classroom blocks. The Education Act of 1961 proposed and implemented the establishment of a Local Education Authority that spearheaded the implementation of the Act in every part of the country. During that time, Ghana had a very steady educational system that most sub-Saharan African countries did not have (Akyeampong, 2009). However, just like the 1951 education policy, the number of school-going age children increased with no corresponding increase in infrastructural development. Thus, the quality was compromised as the period witnessed $65 \%$ of untrained teachers in the system (Akyeampong \& Furlong, 2000). This development became true for what Dewey (1938) and Tyack and Cuban (1995) wrote that educational policies and reforms have always fallen below expectations regarding quality for centuries. Again, the policy provisions did not consider the rural-urban inequity in access and participation. Anlimachie (2015) has indicated that the lack of consideration for the differences in rural and urban settings when formulating educational policies has been one of the limiting factors for the success 
of educational reforms. Thus, Anlimachie (2015) proposed targeted strategies than a widespread implementation of policies in the country.

Between 1961 and 1987 there were two informative reviews, the 1966 Kwapong Review Committee, and the 1974 Dzobo Review Committee. The main recommendations of the 1966 Kwapong Review Committee were increasing the number of years spent in primary school from six years to eight years and an emphasis on pre-vocational education (Akyeampong, 2007). The main features of the 1974 Dzobo Educational Review Committee reports were the introduction of compulsory three-year junior secondary school and the replacement of Common Entrance Examination with Basic Education Certificate Examination (BECE). Again, there was an emphasis on teaching pre-technical and pre-vocational subjects at the junior secondary school level. Thus, the review aimed to introduce a comprehensive Junior Secondary School system that will equip pupils with practical skills. The aim was to introduce pupils into the world of work (Tagoe, 2011). The implementation of the 1974 Dzobo Educational Review Committee recommendations also faced some challenges. The Ghanaian economy was in shambles, and this affected the supply of instructional materials to schools across the country. The shortage of teachers persisted as well as textbooks. According to the Ghana Statistical Service (2003), the decline in the Ghanaian economy during that period witnessed teachers leaving Ghana to work in Nigeria (Ghana Statistical Service, 2003).

1987 education reform is popularly noted for introducing the Junior Secondary School (JSS) and Senior Secondary School (SSS) concepts. The Reform was an improvement on the 1974 Dzobo educational review. Areas addressed in the report include improving access to primary education, addressing the disparities between secondary school and the middle school regarding continuation from the basic level. Again, the reform emphasized the need to improve the quality of education in the country. All the educational reforms Ghana made provisions for the inclusion of practical skills training. However, they all failed to implement the hands-on training aspects of the school curriculum entirely (Little, 2010). The 1987 education reform recommended the following structure for Education: Six years of primary education, three years of Junior Secondary School, three years Senior Secondary School, and four years of University education. The reform endorsed the instructional school curriculum proposed by the 1974 Dzobo Educational Review Committee (Inkoom, 2012). According to Inkoom (2012), the reforms failed because there were no adequate supplies of trained teachers for the pre-vocational and pre-technical subjects. None the less, the ideas of the 1987 education reforms were transferred to the 2007 educational policy reforms.

\subsection{Quality Issues in Education}

Many writers have tried to explain why educational policies fail. Notable among them is Ali (2006). According to Ali (2006), most educational systems failed because of a lack of commitment by the government to implement the policies to the fullest. According to Aissat and Djafri (2011), the inefficiencies in the school system led to the introduction of the outstanding payment by results, whereby teachers, school administrators, and managers were paid depending on the performance of the pupils they teach. Boyle et al. (2007) also mentioned the desire for cheap labour in farms as one of the reasons for the low enrollment rates in the three regions up north. In other related studies, Wilder (2014) and Groves and Baumber (2008) stated that the crucial role of parents in the successful implementation of any educational reform or policy had led policy-makers to re-think about the involvement of parents in school activities including decision-making. Goodall and Montgomery (2014), Cooper (2009) and Kim (2009) also share the same view concerning parental engagement in school programs or activities and decision-making. It is against this background Smith (2000) and Turney and Kao (2009) observed that school authorities neglect the needs of families when structuring decisions for school and parents' engagement (Smith, 2000; Turney \& Kao, 2009). In connection with this believe Crozier and Davies (2007) think that a one size fit for all measures for promoting parental engagement must not be encouraged because parents have different needs, different aspirations, and different work schedules. Ghana is thinking about raising the quality of education and at the same time making education free and compulsory for all school-going age children (Ntim, 2014; UNICEF, 2012). A Columnist like Baidoo (2015) has a different perception of free education. Baidoo (2015) thinks that free education is not right for Ghana under the current economic instability because to allow the funding of education programs for governments alone will adversely affect the school system. The current argument concerning whether education is free or not add up to what Amoah (2015) stated that the issue of free education in Ghana would slow down the training business.

Obeng-Asamoa (2016) caution that educational policies must ensure that children with disabilities have the opportunity to access education. In a related study, Mwin (2016) supports the initiatives put in place by the government to support children with disabilities. According to Mwin (2016), the launch of the inclusive education policy will contribute substantially to identify strategies for educating children with special educational needs. Also, Kuyini and Mahama (2014) mentioned that every Ghanaian child must have access to formal education because it is their right. Recently, there has been advocacy on girl child education to close the gap between the number of boys who have access to formal education to that of girls. To this public opinion, Sackey (2008) and Charnor (2015) 
mentioned that the FCUBE policy reform came to address the issue of the educational system injustices to the vulnerable in Ghanaian society by assisting the girls and other vulnerable members in society including the poor to gain access to primary education (Sackey, 2008; Charnor, 2015). As of 2010, the population of 3 years and older by school attendance was $646,608(100 \%)$. Out of this number, only $256,955(38.7 \%)$ were enrolled as in 2010 (Ghana Statistical Service, 2012; Ghana Statistical Service, 2014). The situation may be different now, but until there is another census, these figures remain valid. Again, according to Yusif and Yussof (2010), data covering enrolment figures for primary schools, junior high schools (JHS) and senior high schools (SHS) in Ghana for the period 2001 to 2008 show improvement. According to Telli (2012), there are other indirect costs of education which include payment for books, school bags, uniforms, pens and pencils and all other materials required by the school for pupils to learn effectively. As and when parents cannot afford these materials their wards mostly drop out of school. Given this, Poku, Aawaar and Worae (2013) and Godwyll (2008) also associated the failure of most educational reforms in Ghana to wrong implementation strategies and lack supervision. Again, Earley, Bubb, Eddy-Spicer, Crawford \& James (2016) have indicated that heads of educational institutions have a critical role to play in the supervision process but also require external advisers to serve as watchdogs for their activities.

The lack of political commitment often leads to poor implementation of educational policies. It becomes worse when governments begin to play partisan politics with educational issues such as under-estimating the situation in schools (HakiElimu, 2002). According to Cox (2013), parents are sending their wards to low-fee private schools because they have lost confidence in public schools. The new development has come with its challenges as private schools are calling on governments to assist them (Ayanful, 2016). Meanwhile, the Ministry of Education (2015) has announced investments in developing the education sector. An investment in the education sector is commendable according to Abdallah, Fuseini, Abudu and Nuhu (2014) because providing resources to schools will promote development. Lamiell (2012) and Siewobr (2015) suggested that developing countries can learn from successful models of other countries. For example, the Malaysian government focused on the education sector and used that to develop its economy. To further enhance success in the education sector Danso (2013), Villines (2014) and Pinto (2014) suggested that politicians can begin to involve teachers on educational policy matters. Decision-making must involve all parties in a unit from bottom to the top-level management as a way of ensuring that policies are implemented to the latter (Danso, 2013; Pinto, 2014; Villines, 2014).

In the light of this, many educational set-ups are battling with poor output and that explains why the Ghana News
Agency (2015) reported that the Upper West Region is battling with its educational system because of the poor performance over the years. Brazil has done well over the years with its bold step towards decentralization of the education and health sector policies (Pierce, 2013). That is why Senge (2012) thinks that every new generation has its discourse on what good education should be. There have also been several studies suggesting a direct relation of teachers' performance in class to the motivational levels of pupils whether to stay in school or quit. For example scholars like Osei and Sam (2012), Kocabas (2009), Osei (2006), Asare and Nti (2014) and Adu-Agyem and Osei-Poku (2012) have all testified that having qualified teachers in the classroom go a long way to enhance the school environment thereby motivating pupils to stay in school. According to Paul and Emmanuel (2014), the massive failures we experience can be traced to teachers' related challenges. Hanson (2012) and Apple (2005) had a different view of why educational policies fail. According to Hanson (2012), pupils finish school with no skills to show for it and this has contributed to the refusal of parents to send their wards to school.

\section{Methodology}

The research design for this study is a case study. A good research design according to Frankfort-Nachmias (2008) and Creswell (2009) must reflect theories that informed the study. The study adopted a case study design because the research was conducted in a natural setting and the manipulation of members was not required as in the case of true experimental research. It also does support inductive reasoning which allow the researcher to build ideas from the known to the unknown (Creswell, 2009; Janesick, 2011; Kallet, 2004). Even though Case studies are easy to conduct and analyze, they contain the survey of a case that means that other instances or issues could be miss out (Creswell, 2013; Patton, 2002; Kothari, 2004).

\subsection{The Population, Sample and Sampling Procedure}

The target population for the study includes the staff of Ghana Education Service, at the Regional and Municipal Offices, the headteachers, and teachers in basic schools in the Municipality. Others include the Regional Minister, Municipal Chief Executive, and parents of pupils in the Municipality. The researcher decided to involve these stakeholders of education because they are directly involved in the implementation process of the policy as well as affected by any negative consequence of educational policies in the Municipality. The statistics for the target population in the Municipality stood at 2,164 members (Source: Upper West Regional Education Office EMIS, 2015). The operational sample size was determined using Tables (Sarantakos, 1998, p. 163). From the Tables, 
the accessible population size of 2,164 attracted a sample size of 564 which is the accumulation of the population samples for all the categories. However, the researcher used a smaller sample size of 356 which is acceptable in qualitative studies (Creswell, 2009). Though a larger sample size is considered appropriate for research (Creswell, 2013), the choice of sample size is informed by the desire of the researcher to select a sample that must ensure greater economy for the research regarding cost and time (Frankfort \& Nachmias, 2008; Creswell, 2013). Table 1 illustrates the population and sample size per group of members.

Table 1. The Sample Size

\begin{tabular}{|l|c|c|}
\hline Members & $\begin{array}{c}\text { Number of } \\
\text { Members }\end{array}$ & $\begin{array}{c}\text { Number of } \\
\text { Members Selected }\end{array}$ \\
\hline Regional Minister & 1 & 1 \\
\hline Chief Executive & 1 & 1 \\
\hline $\begin{array}{l}\text { Regional Director of } \\
\text { Education }\end{array}$ & 1 & 1 \\
\hline $\begin{array}{l}\text { Municipal Director of } \\
\text { Education }\end{array}$ & 1 & 30 \\
\hline $\begin{array}{l}\text { The Staff of Regional } \\
\text { Education Office }\end{array}$ & 62 & 32 \\
\hline $\begin{array}{l}\text { The Staff of Municipal } \\
\text { Education Office }\end{array}$ & 69 & 80 \\
\hline Headteachers & 1774 & 160 \\
\hline Teachers & 50 & 50 \\
\hline Parents & 2164 & 356 \\
\hline Total & Un & \\
\hline
\end{tabular}

(Source of Number of Members: Upper West Regional Education Office, Education Management Information System (EMIS), 2015)

In the process of sampling, sampling error and sampling bias are two major threats to the validity of the research findings (Kothari, 2004). Two sampling strategies were used to minimize both the sampling error and sample bias (Patton, 1990; Kothari, 2004; Creswell, 2013). Thus, purposive sampling and simple random sampling proposed by Patton (1990), Denzin, Lynham and Guba (2011), Creswell (2013), and Kothari (2004) were utilized to select the sample. The lottery method in random sampling was applied in selecting members of both the Regional and the Municipal Education Office staff. Purposive sampling was used in selecting the Regional Minister, the Municipal Chief Executive and the Regional and Municipal Directors of Education. The other members that were selected using purposive sampling were the headteachers, teachers, and parents. The reason for using purposive sampling was to ensure that persons with information about the policy were contacted for the research.

\subsection{Data Collection Instruments and Procedure}

Two data collection designs were used to collect the data for the study. They include a questionnaire, an interview guide. The Questionnaire has the advantage of eliciting personal and intimate information because anonymity is mostly assured. Eleven (11) questions were submitted on both the questionnaire and the interview guide. The first two items sought demographic information of the members regarding their gender and occupation. The other nine (9) items provided answers to the research questions. Some of the items were based on a five-point rating scale with options from strongly agree to undecided. Open-ended and closed-ended questions techniques were also utilized. The questionnaires were administered directly but in some cases through correspondence. All the interviews were by direct interaction with the members. The intervention and efforts yielded a 98\% participation rate for the questionnaires and a $100 \%$ participation rate for the interviews. Eight weeks was used to collect the data for the research. A pre-test to test the internal consistency and appropriateness of the instruments was conducted. Corrections were made to improve the instruments before it was applied to the larger population. Content-related validity determined the validity of the instruments. Inter-rater reliability was also used to verify the reliability of the instruments.

\subsection{Data Analysis Plan}

The embedded design in mixed methods research is used to analyze data (Creswell, 2015). The researcher noticed that a single strategy approach would not be sufficient to analyze the data gathered for the research. The analysis design for the study is largely qualitative but would require supplementing the analysis with quantitative analysis (Creswell, 2015). Two data analysis strategies were employed. The first one includes using descriptive statistics to compute data on closed questions into frequencies, percentages while the second approach was a thematic analysis of data. The thematic analysis involves summarizing data on open questions into themes relevant to the research questions (Patton, 2002). With the thematic analysis, data was translated from broad perspectives into patterns for interpretation.

\section{Results and Discussion}

Data Analysis on Gender and Occupation of Members presented in Figure 1 and Table 2

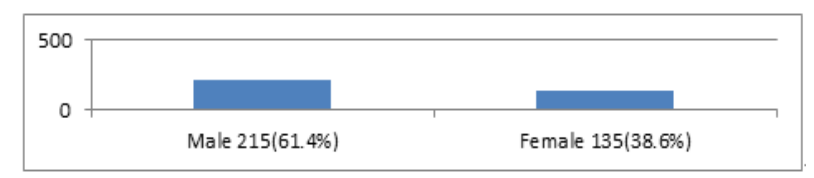

Figure 1. Graphical Presentation of Number of Male and Female Participation 


\subsection{How Relevant are the Provisions made for the FCUBE in Ghana's 2007 Educational Policy to the People in the Wa Municipality?}

Data on the relevance of the provisions raised for the FCUBE policy are presented in Figure 2. To pave the way for a three-side perception in the discussion and convenience in the analysis as suggested by Creswell (2015) and Patton (2012) very relevant and relevant are merged to mean relevant. Out of the 350 members that participated in the research $305(87.1 \%)$ think that the FCUBE policy is relevant, $43(12.3 \%)$ believe that the FCUBE policy is not relevant, whereas $2(0.6 \%)$ said they cannot tell. It is crystal clear that most members think that the policy is relevant whereas a little minority believe that the policy is not relevant.

Members were asked to give reasons for their choice of answers in Figure 2. The results for members who think the policy is relevant are presented in themes in Figure 3.

Table 2. Occupation of Members

\begin{tabular}{|c|c|c|c|c|c|}
\hline \multicolumn{2}{|r|}{ Variables } & Frequency & Percentages & Valid Percentages & Cumulative Percentages \\
\hline Valid & Regional Minister & 1 & 0.3 & 0.3 & 0.3 \\
\hline & Municipal Chief Executive & 1 & 0.3 & 0.3 & 0.6 \\
\hline & Regional Director of Education & 1 & 0.3 & 0.3 & 0.9 \\
\hline & Municipal Director of Education & 1 & 0.3 & 0.3 & 1.2 \\
\hline & The Staff of Regional Directorate of Education & 30 & 8.6 & 8.6 & 9.8 \\
\hline & The Staff of Municipal Directorate of Education & 32 & 9.1 & 9.1 & 18.9 \\
\hline & Headteachers & 80 & 22.8 & 22.8 & 41.7 \\
\hline & Teachers & 154 & 44 & 44 & 85.7 \\
\hline & Parents & 50 & 14.3 & 14.3 & 100 \\
\hline & Total & 350 & 100 & 100 & \\
\hline
\end{tabular}

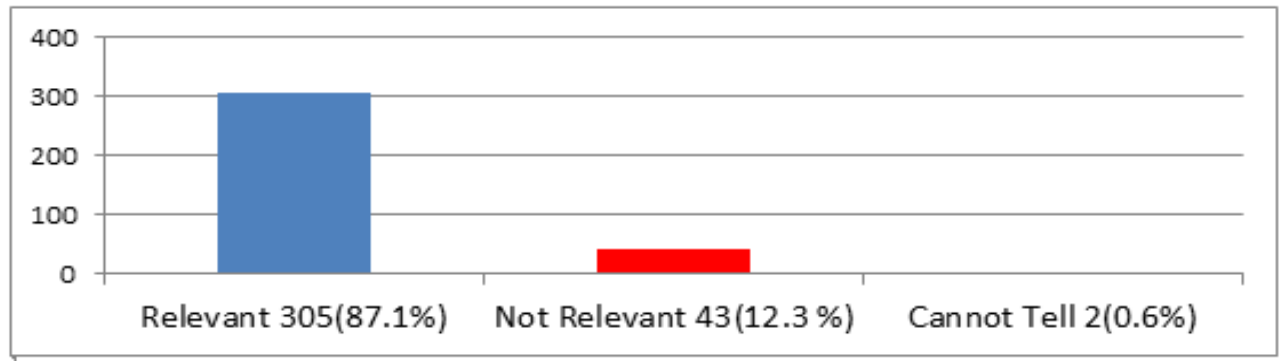

Figure 2. Graphical Presentation of the Relevance of the FCUBE Policy

\section{Reasons members advance to support the claim that the FCUBE policy is relevant}

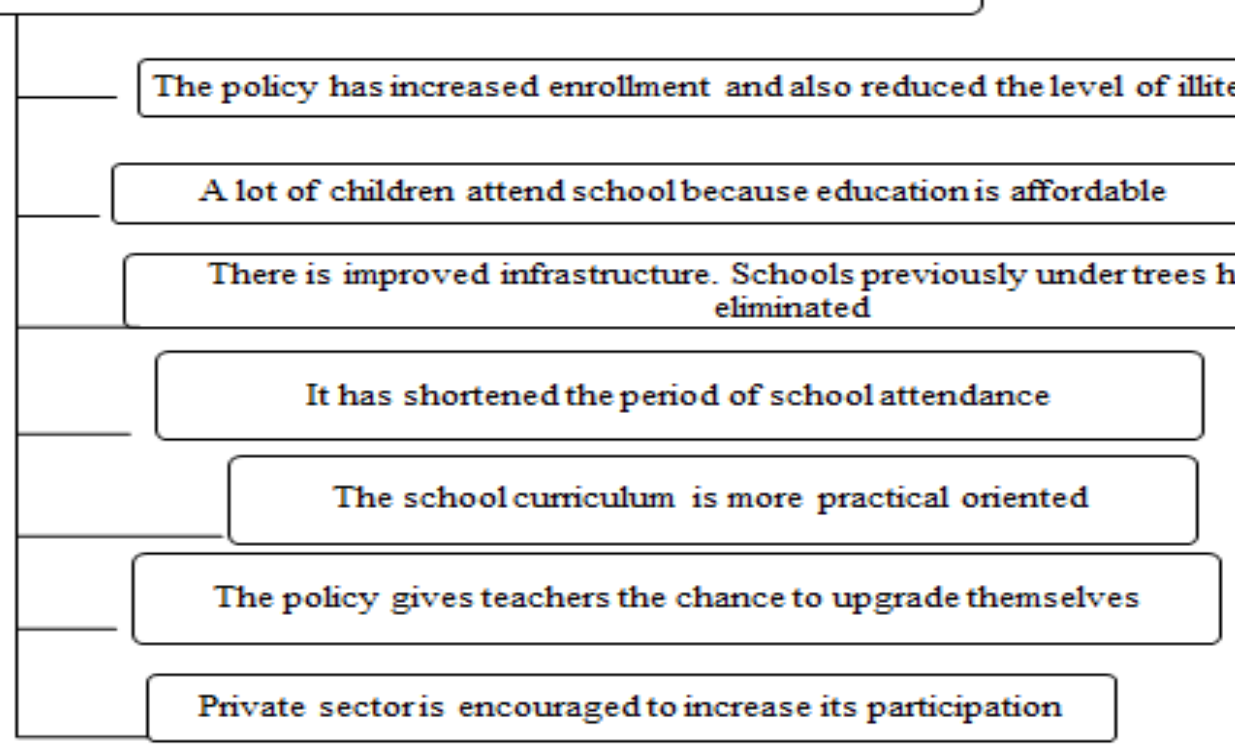

Figure 3. List of Themes to Support the Statement that the Policy is Relevant 


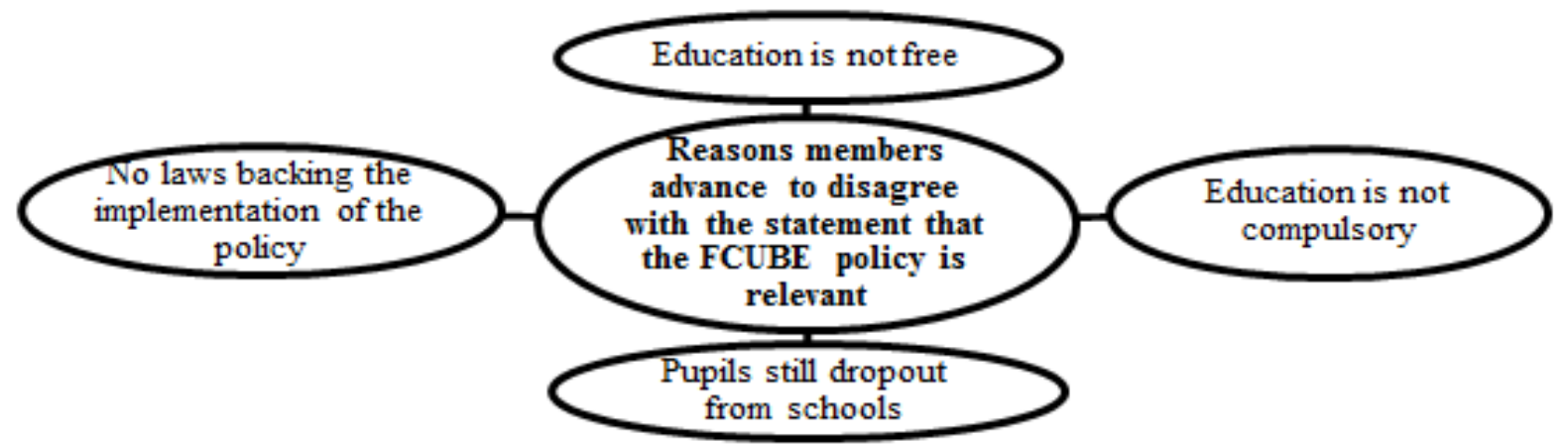

Figure 4. List of Themes Identified that Disagree with the Statement that the Policy is Relevant

Members 305(87.1\%) were of the view that the FCUBE policy is relevant because it has increased the number of children attending school in the Municipality. The current findings go to support what Kuyini and Mahama (2014) said that every Ghanaian child has the right to quality education. Next on the list of themes is the view that lots of children can now attend school because education is affordable. In other words, parents are not required to pay tuition fees. The policy puts more responsibility for parents because it is compulsory for them to send their children to school. Other themes also include teachers having the chance to upgrade their skills and knowledge to enhance their performance. The current observation goes to support the findings of Kocabas (2009) which says teacher motivation level is closely linked to their level of performance. There were $43(12.3 \%)$ members who think that the FCUBE policy is not relevant. The reasons they advanced for their views are presented in Figure 4.

The first to be discussed is that education is neither free nor compulsory. A little minority of members think that the policy is not relevant because education is not free and compulsory in the Wa Municipal. According to members parents still pay school fees, pay monies for sports, canteen, the printing of exams papers, purchase of cumulative cards, buying of furniture and other learning materials. A report by Boyle et al. (2007) submitted to USAID-Ghana also confirms the current view on why the policy is not relevant. Thus, the indirect cost of education is still a burden on parents. Again, members stated that education is not compulsory in especially in rural communities. The observation goes to confirm what Yusif and Yussof (2010) stated that though the Upper West Region has achieved significant growth in enrollment figures over the years, the number of children outside of school is still large (Yusif \& Yussof, 2010).

\subsection{Will You Say the Implementation of Ghana's 2007 Educational Policy Has Brought Free and Compulsory Education to the Wa Municipality?}

The results are displayed in Figure 5.

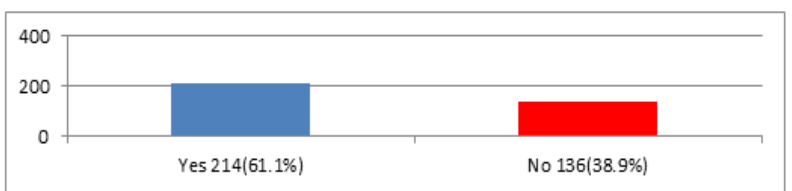

Figure 5. Graphical Presentation of Results on Free Education

From the information displayed in Figure 5, a majority of $214(61.1 \%)$ members think that education is free in the Municipality. Whereas a minority of $136(38.9 \%)$ members believes that education is not free. Five common themes that support the statement that education is free in the Municipality were identified and presented in Figure 6.

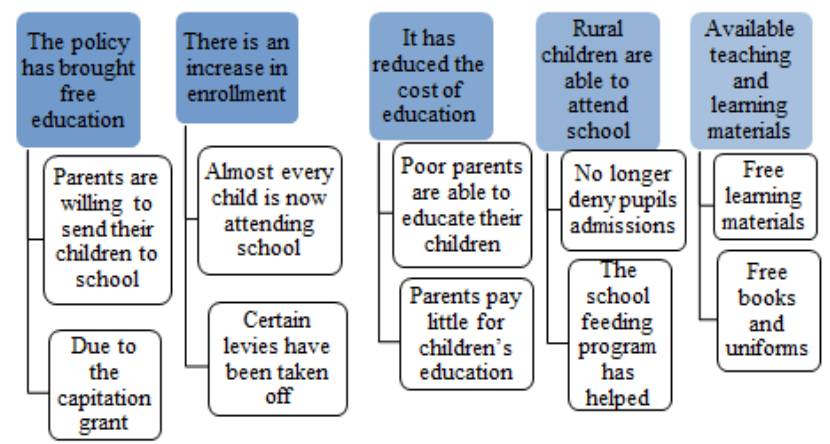

Figure 6. List of Themes and Sub-Themes that Support the Statement that the Policy has Brought Free Education to the Wa Municipality

Most members 214(61.1\%) indicated that the policy had brought free education to many children in the Wa Municipality. The reasons are presented in Figure 6. Contrary to this perception is a report by Nordensvard (2013), who described Ghana as a country that cannot implement a universal educational system. Closely related to Nordensvard (2013) submission is a report by Cox (2013) who mentioned that many private schools are springing up across all regions in the country because the people have lost hope in the public education system. Some minority members $136(38.9 \%)$ did not share the view that the policy has brought free education to the Municipality. The reasons to support their submissions are presented in Figure 7. 


\section{Reasons submitted for disagreing with the statement that the policy has} brought free education to the people in the Wa municipality

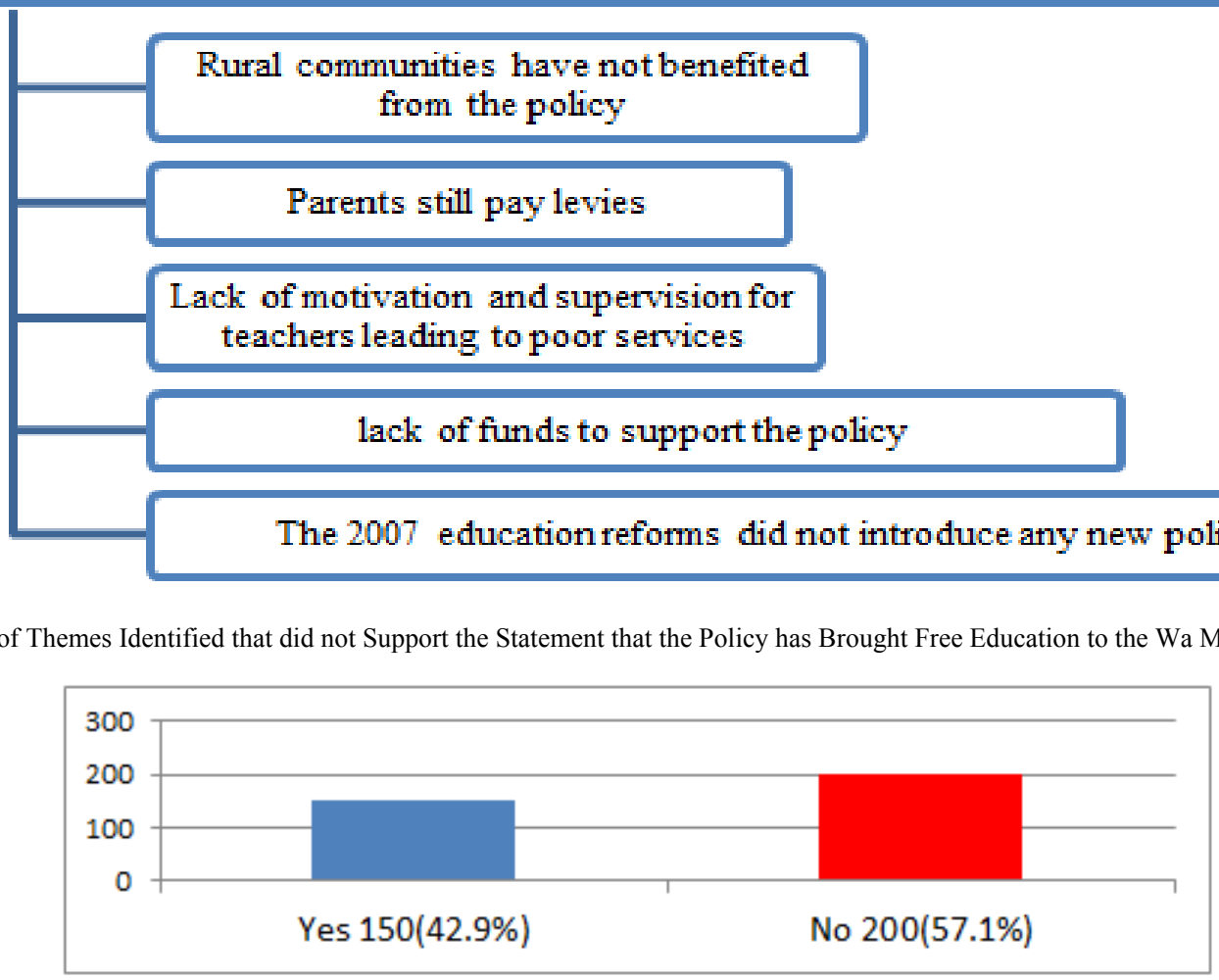

Figure 7. List of Themes Identified that did not Support the Statement that the Policy has Brought Free Education to the Wa Municipality

Figure 8. Graphical Presentation of Results for Compulsory Education in the Municipality

The 136(38.9\%) minority members think that most children from rural communities do not benefit from the free education policy. The viewpoint supports what Anlimachie (2015) indicated that the lack of consideration for the differences in rural and urban settings when formulating educational policy affects the successful implementation of educational reforms. Tagoe (2011) also reported that regional figures of enrolment rates do not often take into consideration low admission rates in rural communities. Other themes include the inability of parents to pay levies, the lack of motivation and supervision for teachers leading to poor services and the lack of funds to execute the provisions made in the 2007 education policy. The major drawback according to members is the lack of fund to implement the 2007 education policy and that has made the policy irrelevant and dysfunctional. Information on how the Ghana 2007 educational policy has made education compulsory at the basic level was also submitted. Thus, a smaller number of members $150(42.9 \%)$ believe that education is compulsory in the Municipality, whereas a larger majority of members $200(57.1 \%)$ think that education is not compulsory in the Municipality. The results are presented in Figure 8.

Again, members were asked to indicate the reasons for their choice of response in Figure 8. Four common themes were identified to support the statement and are presented in Figure 9.

To support their submission that Ghana's 2007 educational policy has brought compulsory education to the Municipality, members stated that every child of school-going age has the right to education. This has mandated parents to send their wards to school. The suspension of payment of tuition fees has given needy parents the motivation to send their children to school. The current finding is an improvement to what Nordensvard (2013) stated that as at 2007 a million school-going age children were out of school while about $20 \%$ of school-going age children drop out of school before they reach high school (Nordensvard, 2013). Again, members stated that one of the strategies adopted by the policy to create an enabling environment to sustain pupils in school is the motivation given to teachers. The objective is that quality teaching will sustain pupils' interest in education and keep them in school. 


\section{Reasons to support the statement that the policy has brought compulsory education to the people in the Wa municipality}

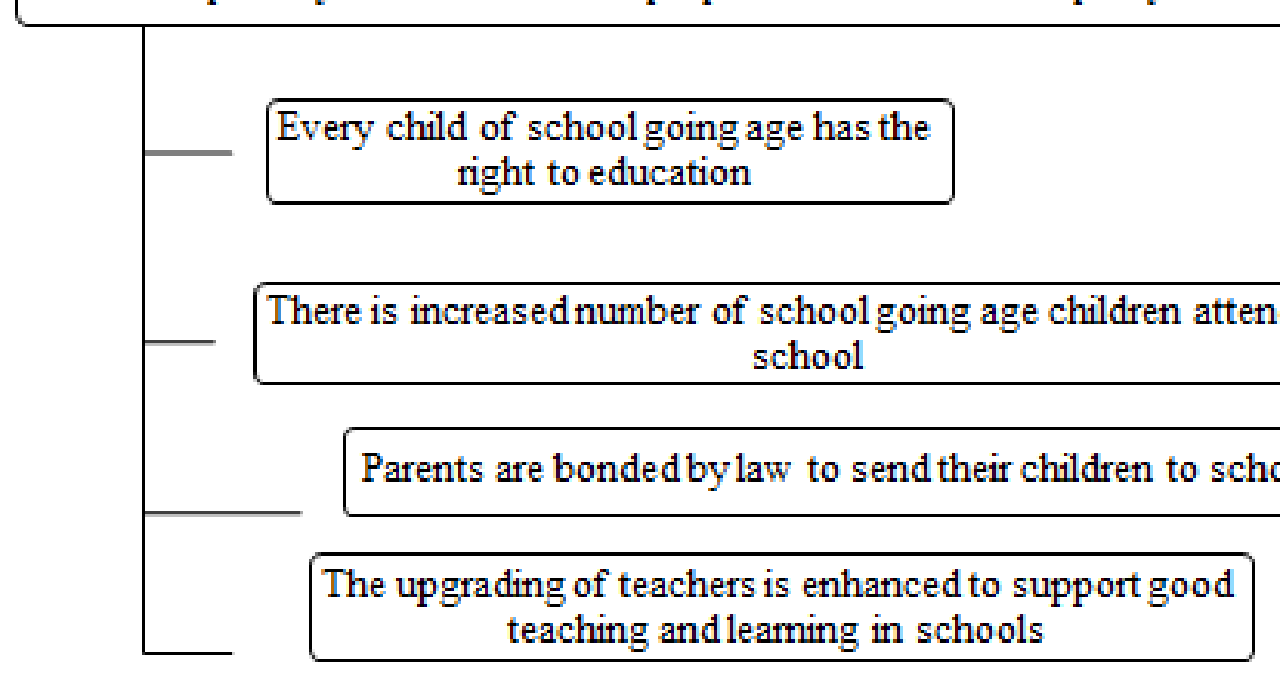

Figure 9. List of Themes Identified that Support the Statement that the Policy has Made Education Compulsory in the Wa Municipality

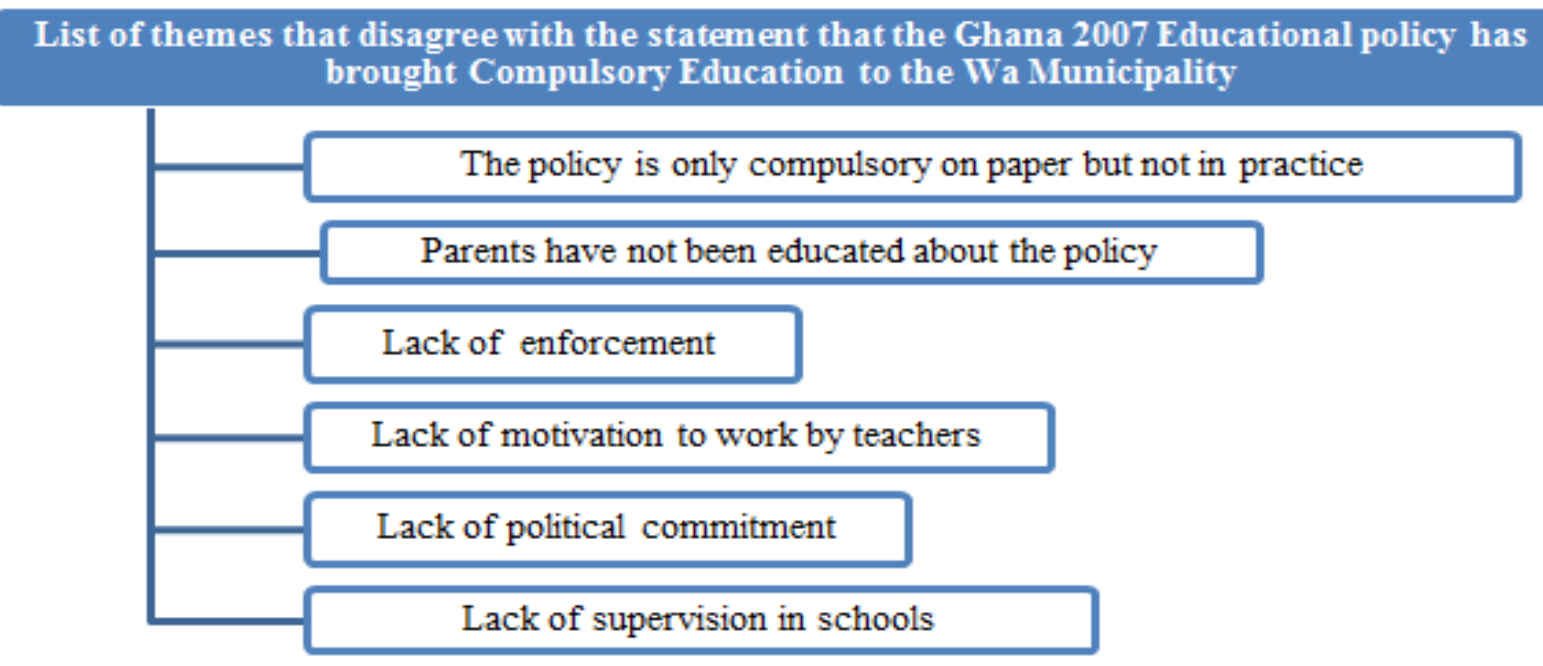

Figure 10. List of Themes that Disagree with the Statement that Ghana's 2007 Educational Policy has brought Compulsory Education to the Wa Municipality.

Contrary to the view that education is compulsory in the Municipality is most members think that education is not compulsory in the Municipality. Seven common themes were identified and presented in Figure 10 above. Most members 200(57.1\%) indicated that the provision made in the policy for compulsory education has not been implemented. Members described the policy as a constitutional provision that lacks the power of enforcement just like past policies. The next theme on the list is the issue of public education. Members have the opinion that parents have not been educated about the policy and because of ignorance some parents still prefer to keep their children at home. Wilder (2014) reported that there is a focus by teachers, administrators, and policymakers on parental involvement in academic activities of pupils as an integral part of new educational initiatives. Goodall and Montgomery (2014) also identified a continuum between parental involvement with schools and parental engagement with children's learning. When parents are involved with their children's learning the furthest, they are associated with the end of the proposed continuum. Therefore, it suggests that public education about the policy and other matters concerning education will get the parent to be more involved in the affairs of their children education.

The next theme on the list is about lack of enforcement of the law to compel parents to send their wards to school. This observation comes from the fact that parents who did not send their children to school are not punished. Thus, the compulsory aspect of the policy is not enforced by law. The lack of motivation to work by teachers due to poor conditions of service is next on the list. The implication 
here is that once teachers refuse to work the learning environment is weak and pupils stay away from school. Anamoah-Mensah (2002) who shared the same views with UNICEF (2012) acknowledge that inadequate infrastructure to accommodate school children and support teachers have brought the operation of many schools to a standstill in terms of teaching and learning. Members think political leaders concentrate more on politics and how to win the next election than ensuring that policy provisions are implemented accordingly. That is why Ali (2006) thinks that educational policies fail because of lack of political commitment, unclear policy goals, overly centralization of decision-making, lack of resources, and over-dependence on foreign aid. According to Osei and Sam (2012), the School Management Committees (SMC) has done very little in the monitoring and supervision of headteachers, teachers, and pupils and that has resulted in the abysmal performance of teachers and pupil.

4.3. What Factors Affect the Implementation of Ghana's 2007 Educational Policy Regarding Free and Compulsory Education in the Wa Municipality?

The findings are presented in Figure 11

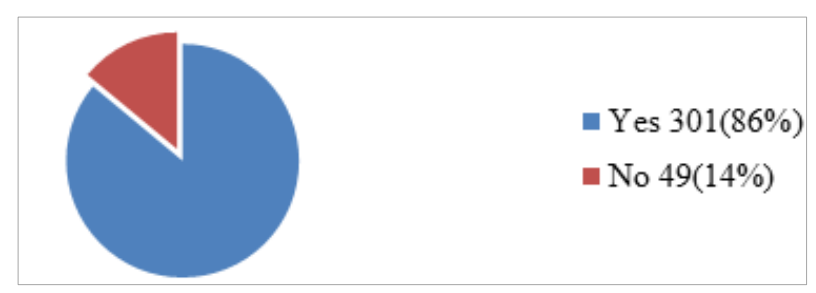

Figure 11. A Pie Chart indicating whether Factors are affecting the Implementation Process

Most members representing 301(86.0\%) said factors were affecting the policy implementation in the municipality, whereas a little minority of members representing $49(14.0 \%)$ stated that no factors are affecting the process. The reasons members submitted to support the statement were categorized into ten common themes presented in Figure 12.

\section{List of themes supporting the statement that there are factors affecting the implementation process}

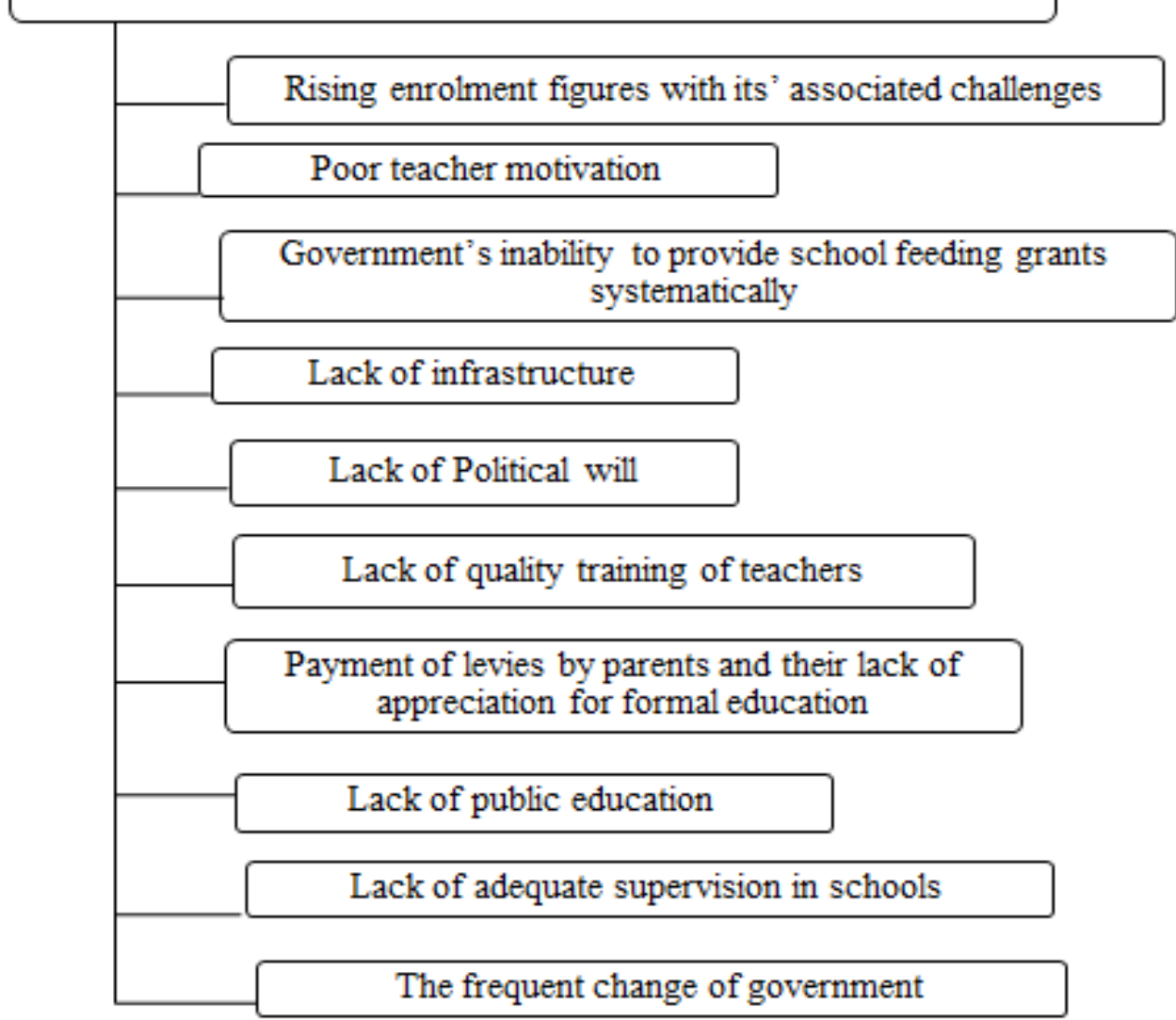

Figure 12. List of Themes that stated that Factors are affecting the Implementation Process in the Wa Municipality 
Members believe that one of the challenges is the attempt to increase enrollment without considering the quality and that makes the progress of pupils difficult. Poor teacher motivation is also identified as a factor affecting enrollment. Members indicated that teachers are not adequately motivated, and it prevents them from executing their job diligently. Members mentioned that school authorities find it difficult in accessing capitation grants. It negatively affects the provision of meals for pupils resulting in absenteeism and subsequently pupil dropping out of school. The next theme is on Lack of infrastructure. Members think the lack of infrastructure and resources has adversely affected the ability of schools to enroll more children. Again, according to members, some communities in the Municipality have no schools and children have to foot miles to nearby schools to access education. Most of the children quit schooling because they cannot cope with the situation. To support this finding Apple (2005) mentioned that the lack of resources to facilitate quality education has led to many children dropping out of school. The lack of political will by government and educational authorities in the Municipality was another factor identified by members. The current findings can be identified with what Ali (2006) said about the lack of government commitment to the implementation of educational policies. The absent of by-laws to prosecute parents who do not send their children to school is one of such examples. The next theme on the list is government refusal to train all teachers in the field to become professional teachers. Government has the responsibility of training all teachers appropriately, but some teachers have not been trained and are serving as pupil-teachers in the Wa Municipality. Contrary to this submission is the report by Charnor (2015) that some teachers without teacher training have outperformed teachers with professional training.

Others are the lack of education about the policy to parents and other stakeholders of education. Parents need education on the importance of formal education because some parents do not see the need to enroll their children in school out of ignorance. Groves and Baumber (2008) noticed this fact and described parents as co-educators who have the potential of regenerating schools. Members also believe that until supervision is effectively done the business of education will continue to register failures and this notion is supported by Osei-Owusu and Sam (2012). Members also indicated the frequent change of government as one of the reasons why it is difficult for the Ghana 2007 education policy to achieve its objectives. The constant change of government is affecting the implementation process because new governments come with new policies. The new policies are never fully implemented before there is another change of administration, and the cycle continues. Some minority of members $49(14 \%)$ believe that there are no factors adversely affecting the implementation process. Four common themes were identified and presented in figure 13.

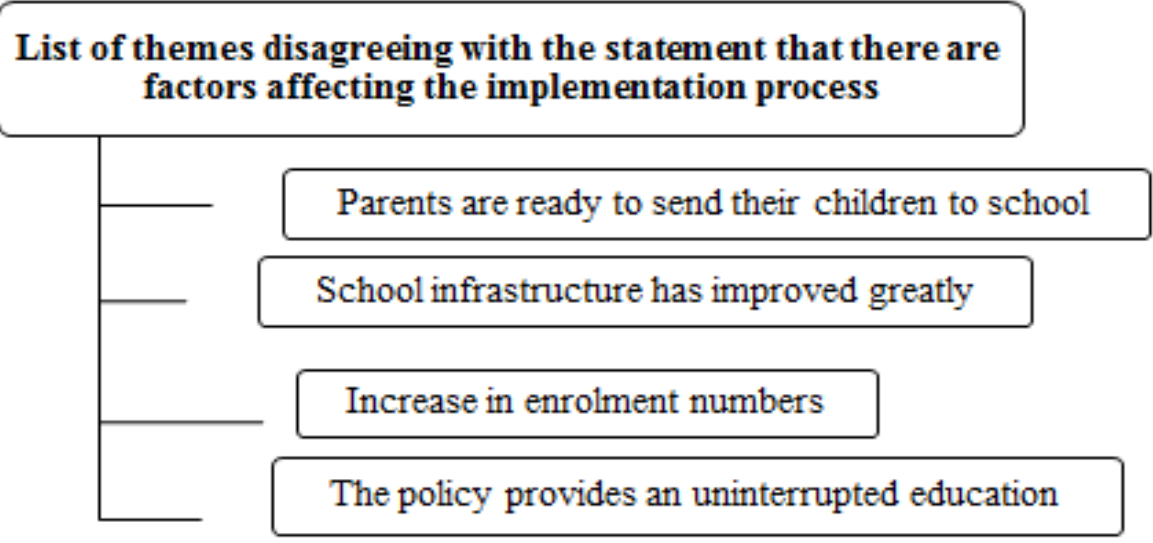

Figure 13. List of Themes Identified which says that no Factors are affecting the Implementation Process in the Wa Municipality

Members stated that the implementation of the policy had compelled parents to send their children to school. The policy has given all the children in the Municipality the chance and opportunity to go to school and that adequate facilities in the form of infrastructure to accommodate the increasing numbers of children enrolled each year have been provided. The increase in enrollment figures has been supported by other researchers like Yusif and Yussof (2010); UNICEF (2012); and Anlimachie (2015) who reported that there is a tremendous increase in the number of children attending school in Ghana and the Wa Municipality is inclusive.

\subsection{What Strategies Can Enhance Maximum Implementation of Free and Compulsory Education in the Wa Municipality?}

The section provides data for strategies to improve maximum benefits for free and compulsory education. Ten common themes were identified the results are shown in Figure 14. 


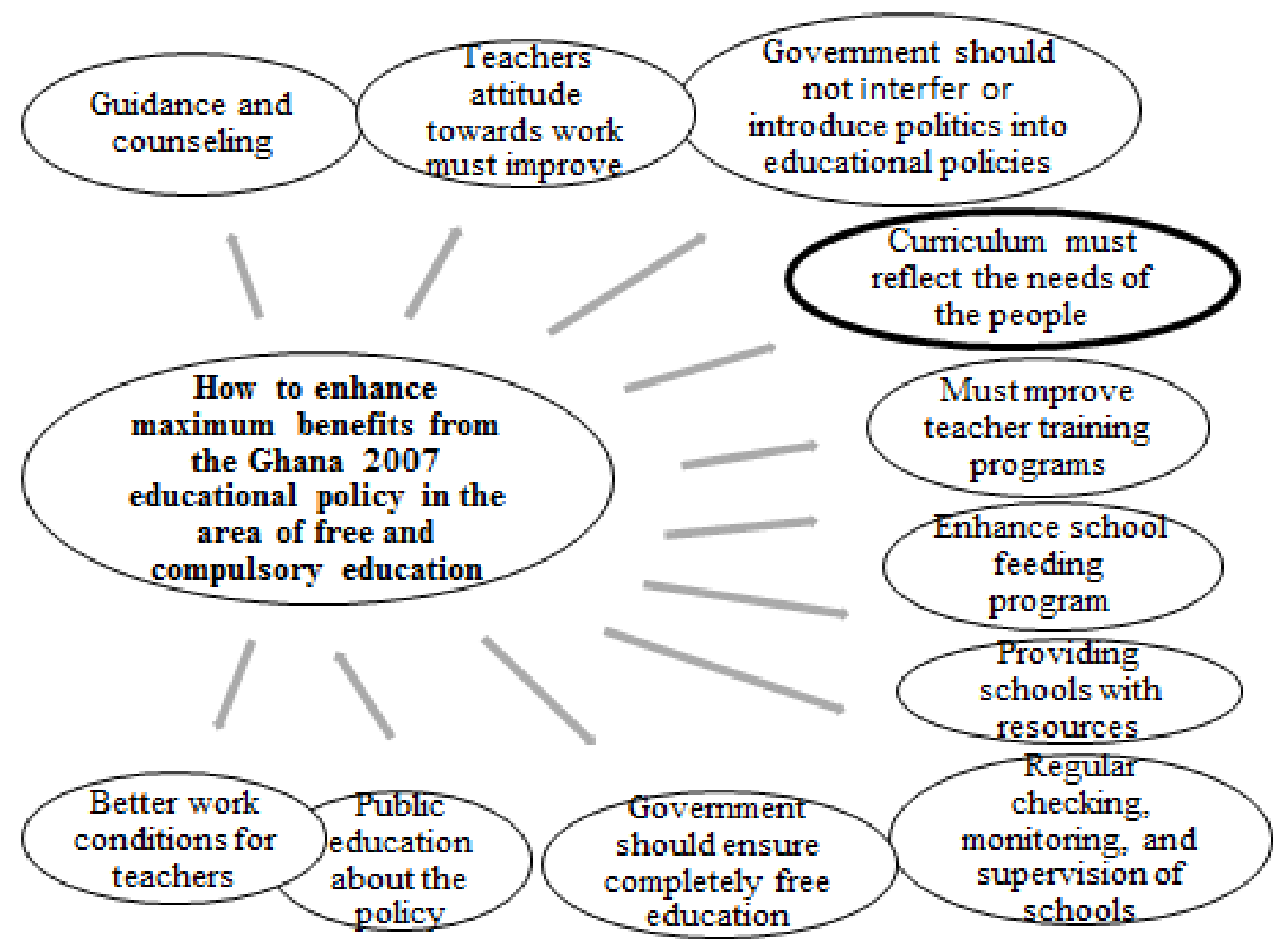

Figure 14. List of Themes Identified that Suggest how Maximum Benefits can be derived from the Policy concerning Free and Compulsory Education

Guidance and counselling were identified as one of the strategies that can ensure maximum benefits from the policy. Members also think that teachers should discharge their duties diligently. This suggestion was made based on the perception of members that teachers' attitude toward work is poor. The current suggestion supports what Akyeampong and Furlong (2000) stated that teachers are not committed to the practice of instruction. Members also stated that teachers must be part of the formulation of educational policies to increase their acceptance levels. The current suggestion goes to support what Danso (2013) said that politicians are very much involved in the policies of the education sector to the neglect of the education technocrats. The next suggestion was that the government should not interfere or introduce partisan politics into educational policies because it is detrimental to the development of education. According to Thomas (2012), it will be difficult to disassociate politics from education matters because an educational policy is an extension of the political system (Thomas, 2012). We can comfortably say that Dewey (1938) idea about the politicization of education is still relevant in contemporary times because educational policies are still handed down from top to bottom. Members also suggested that the curriculum must reflect the needs of the people by including more social intervention programs that will address the needs of the pupils and their community. The current suggestion is supported by Poku, Aawaar and Worae (2013) who reported that educational reforms fail for lack of social, political, and economic considerations. On the economic front, industries do not receive the right workforce from schools (Poku et al., 2013). Thus, people must be retrained to fit into the job market after years of schooling.

Issues relating to the improvement of teacher training programs were also suggested. The observation supports what Asare and Nti (2014) noted that the quality of a teacher is very crucial to the successful implementation of any educational policy (Asare \& Nti, 2014). The next theme identified concerns the enhancement of the school feeding program. According to members' submission, the delays in payment of capitation have posed a lot of challenges for many basic schools. The timely and adequate release of capitation grants will enable school authorities to plan effectively. The next theme was on the provision of resources to schools. The Municipality lacks both material and human resources and that has a negative direct impact on enrolment. They believe if resources are provided schooling would be more comfortable for pupils and sustain them in school. This suggestion is supported by Eyiah (2013) who mentioned that school infrastructure in the form of buildings influences pupil's mindset about schooling and its essence. 
Members also identified regular checking, monitoring, and supervision of teachers very important. According to members, teachers and headteacher will work effectively and efficiently when they are under monitoring and supervision. It is against this background that Earley et al. (2016) recounted the oversight role external advisers' play in improving the performance of school leaders because to achieve the objectives of educational policies lies at the heart of effective school leadership. Another theme that was identified concerns the ability of the government to allow and ensure completely free education by disallowing parents to pay levies. Writers like Baidoo (2015) and Amoah (2015) believe that free education is not right for Ghana under the current global economic instability because it will uphold quality education. Parents can be encouraged to send their children to school through public education especially on local FM stations. Proper education on the punishment for parents who refuse to send their children to school will promote the compulsory aspect of the policy. The last theme under this segment was on better work conditions for teachers. Adu-Agyem and Osei-Poku (2012) support this suggestion when they indicated that we could achieve much if teachers that are highly committed to their job (Adu-Agyem \& Osei-Poku, 2012).

\subsection{Proposed Model for Implementing Educational Policies in the Wa Municipality}

From the findings, analysis and discussions, the researcher is recommending an educational policy implementation model that will enable educational leaders at the implementation stage to achieve success. Figure 15 is the proposed model for implementing educational policies, especially in the Wa Municipality. Literature has shown that it is a challenge to implement educational policies even in developed nations like the United Kingdom and the United States (Baidoo, 2015; Dewey 1938; Tyack \& Cuban, 1995). There is a continues lapse in funding education plans and no matter how relevant and useful the policies may be the lack of funding always cause a deficiency in their achievement levels. A look at the proposed model in Figure 15 indicates that the first step is to identify your goal. The goal involves the identification of the task you intend to accomplish. The next step is to determine the resource persons. During the meeting session with the resource persons, the goals are reviewed to enable total acceptance. Usually, people will abide by the decisions they contributed to establish. Once the objectives are clear to the experts, the next step is to allow the group to identify activities that will lead to achieving the goals set up. The activities identified will become the basis for the assignment of the task. The accomplishment of a task will come with some form of financial commitments.

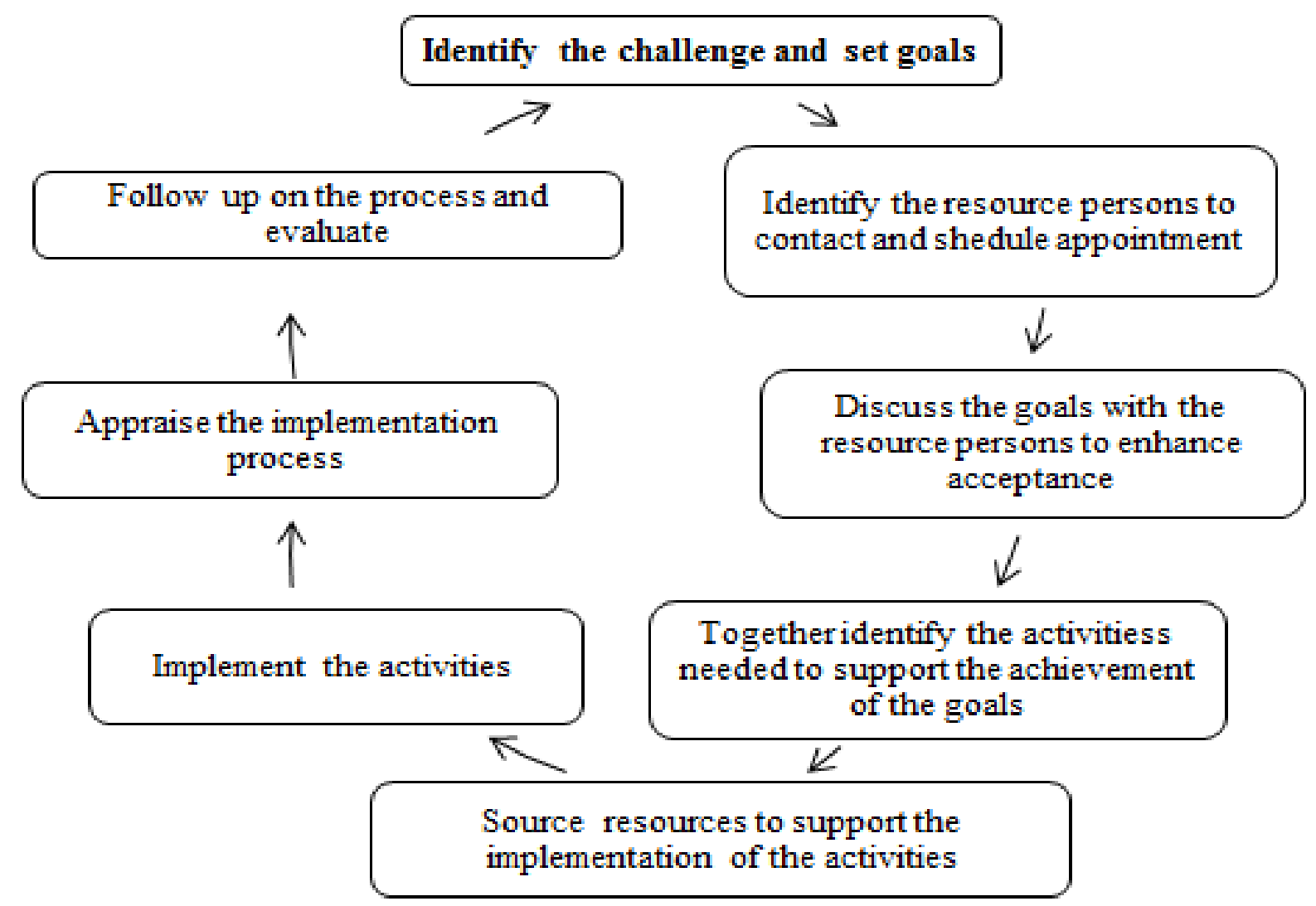

Figure 15. A Directional Cycle Showing the Proposed Educational Policy Implementation Model with its Intended Activities 
Thus, the next task is to source funds. Sourcing funds could be the most challenging activity in the model especially taking the Wa Municipality into consideration where most of the dwellers are peasant farmers and petty traders (Ghana Statistical Services, 2012). Once funds are sourced, the next step is to implement the proposed activities. The process of implementing ideas and or programs is a critical stage in the implementation process. Here leadership must be vigilant and available to aid in the process. However, some leaders chose to rest at this point, and the results are the failure to achieve goals. As part of the monitoring process, educational authorities must conduct appraisal services. The exercise will help to identify the strength and weaknesses of the programs being implemented. The shortcomings can be addressed to enhance maximum success. The process cannot be completed without following up for feedback and evaluation. At every stage of the process, a leadership role is imperative. The efforts from leadership are what will determine the success of the implementation process. It is the area where most leaders fail because they absent themselves from the application process. The most some leaders do is by delegating the monitoring and supervision aspects to persons who are not competent enough to handle the issues. From the model the process does not end with the appraisal, there need to be consistent follow-ups for evaluation purposes. The assessment exercise will determine the next line of action, and that includes setting new challenges and the cycle begins again.

\section{Conclusions}

The research question on how relevant Ghana's 2007 educational policy in the Wa Municipality received majority positive responses. Most members think there has been an increase in enrollment figures as parents are willing to send their children to school. They attributed the increase in enrolment to the introduction of the capitation grant and the school feeding program which came as a relief to many parents. However, a minority of the members think numerous challenges have negatively affected the implementation of the policy. They are of the view that the policy has not introduced free and compulsory education because parents still pay levies while some pupils are not attending school. Some of these challenges include the lack of public education, decrease participation and access in rural communities, the inconsistent flow of money to finance the programmes, poor work conditions for teachers and inadequate monitoring and supervision of the implementation process. Some suggestions were made on how to enhance the implementation of educational policies in the Municipality. The over-reliance on foreign players, aid and remittances to fund education must stop since it is not helping the development of the sector. In the area of enrollment, the ideas include improving infrastructure, and material resources in schools to cater for the increasing numbers of school children. They also suggested better work conditions for teachers, educating the public about educational policies, monitoring and supervision were not left out and disallowing politics to influence educational policies were all identified as solutions that can help governments to fully implement educational policies successfully.

\section{Recommendations}

Based on these findings, the following recommendations are made.

- Internally generated funds must be used to make the school environment learner-friendly by maintaining the already existing structures.

- The Municipality must educate the public through a public forum, during festivals and durbars about educational policies in the Municipality.

- The Municipal Assembly must establish a bylaw to deal with parents who deliberately refuse to send their children to school.

\section{Recommendations for Further Studies}

The scope of the current study is to evaluate the performance of Ghana's 2007 educational policy in enrollment in the Wa Municipality.

1. There are other areas the policy has made provisions for which includes Quality Education, External Inspectorate of Schools, and Technical, Vocational, and Agricultural Education and Training (TVET). Therefore, it would be right to investigate the entire policy for holistic analysis.

2. There are also eleven districts in the Upper West Region and only the stakeholders of education in the Wa Municipality were engaged in the research. The research can be replicated in other districts to widen the scope of the study while comparing performance in the districts. The process will result in an in-depth analysis of the policy of enrollment in the Region and not just the Wa Municipality.

3. The research focused on basic schools and an expansion to include stakeholders of education at the secondary level will provide additional perspective on the issue under investigation.

\section{Contributions to Knowledge}

1. The current research has added to empirical knowledge on the implementation of Ghana's 2007 educational policy in the Wa Municipality. 
2. The research has revealed the level of success the policy has attained in the Wa Municipality with specific reference to the provisions made for free and compulsory education.

3. Some members through the research instruments have come to know more about the policy and are ready to implement the provisions than before.

4. The researcher also presented a model to support the implementation of educational policies.

5. The recommendations submitted could empower decision-making concerning free and compulsory education in the Wa Municipality.

\section{Appendix}

\section{Statistics for Target Population}

\begin{tabular}{|c|c|c|c|}
\hline CATEGORY & \multicolumn{2}{|c|}{ POPULATION } & TOTAL \\
\hline \multirow{2}{*}{$\begin{array}{c}\text { Number of } \\
\text { Headteachers }\end{array}$} & Male & 98 & \multirow{2}{*}{205} \\
\hline & Female & 107 & \\
\hline \multirow{2}{*}{$\begin{array}{c}\text { Number of Teachers } \\
\text { (Trained) }\end{array}$} & Male & 665 & \multirow{2}{*}{1442} \\
\hline & Female & 777 & \\
\hline \multirow{2}{*}{$\begin{array}{c}\text { Number of Teachers } \\
\text { (Untrained) }\end{array}$} & Male & 186 & \multirow{2}{*}{332} \\
\hline & Female & 146 & \\
\hline \multirow{2}{*}{$\begin{array}{c}\text { Wa Municipal } \\
\text { Education Office Staff }\end{array}$} & Teaching Staff & 37 & \multirow[b]{2}{*}{69} \\
\hline & $\begin{array}{c}\text { Non-Teaching } \\
\text { Staff }\end{array}$ & 32 & \\
\hline \multirow{2}{*}{$\begin{array}{c}\text { Wa Regional } \\
\text { Education Office Staff }\end{array}$} & Teaching Staff & 27 & \multirow[b]{2}{*}{62} \\
\hline & $\begin{array}{c}\text { Non-Teaching } \\
\text { Staff }\end{array}$ & 35 & \\
\hline
\end{tabular}

Source: Upper West Regional Education Office: Education Management Information System (EMIS) (2015)

\section{REFERENCES}

[1] Abdallah, H., Fuseini, M. N., Abudu, A. M., \& Nuhu, Y. (2014, September 1). Dilemma of basic school pupils in northern Ghana with respect to their learning context. Education Research International. Retrieved 27th July, 2016 from http://www.hindawi.com/journals/edri/2014/140737/

[2] Adamu-Issah, M., Elden, L., Forson, M., \& Schrofer, T. (2007). Achieving universal primary education in Ghana by 2015: A reality or a dream? UNICEF Division of Policy and Planning Working Paper. Retrieved 7th January, 2016, from http://www.unicef.org/french/videoaudio/PDFs/Achieving Universal_Primary_Education_in_Ghana_by_2015.pdf

[3] Adu-Agyem, J., \& Osei-Poku, P. (2012). Quality education in Ghana: The way forward. International Journal of Innovative Research \& Development, 1(9), 164-177.

[4] Aissat, D., \& Djafri, Y. (2011, April). The role of colonial education in retrospect: The Gold Coast case in the era of imperialism. Retrieved 11th August, 2016 from http://research.unileipzig.de/eniugh/congress/fileadmin/eniu gh2011/dokumente/Mechanisms-of-British-Imperial-Aissat _and_Djafri-2011-04-15.pdf

[5] Akyeampong, K. (2009). Revisiting free compulsory universal basic education (FCUBE) in Ghana. Comparative Education, 45(2), 175-195.

[6] Akyeampong, K. (2007). A review of fifty years of challenge and progress in Ghana: Paper Presented at the Educational Expansion and Access in Ghana. Westminster: Parliament offices.

[7] Akyeampong, K., \& Furlong, D. (2000). Ghana: A baseline study of the teacher education system. Muster Discussion Paper, 7. Retrieved 7th January, 2016, from http://r4d.dfid.gov.uk/PDF/Outputs/SkillsForDev/Muster_ mpd_7_11_02.pdf

[8] Ali, S. (2006). Why does policy fail? Understanding the problems of policy implementation in Pakistan - a neuro-cognitive perspective. International Studies in Educational Administration, 34(1). Retrieved 27th July, 2016 from http://ecommons.aku.edu/pakistan_ied_pdck/10/

[9] Amoah, A. K. (2015, October 2). Running free education, upholding quality. Ghana Web. Retrieved 18th August, 2016 from

http://www.ghanaweb.com/GhanaHomePage/features/Runn ing-free-education-upholding-quality-385024

[10] Anamuah-Mensah, J. (2002). President's committee on review of education: Meeting the Challenges of Education in the Twenty First Century. Accra.

[11] Anfara, V., \& Mertz, N. T. (2006). Theoretical frameworks in qualitative research. Thousand Oaks: Sage Publications Inc.

[12] Anlimachie, M. A. (2015). Towards equity in access and quality in basic education in Ghana: Comparative strategies for the rural and urban milieu. American Journal of Social Issues and Humanities, 5(2). Retrieved 6th January, 2016, from http://www.ajsih.org/index.php/ajsih/article/view/190

[13] Apple, M. W. (2005). Doing things the 'right' way: Legitimating educational inequalities in conservative times. Educational Review, 57(3), 271-293. doi: $10.1080 / 00131910500149002$

[14] Asare, K. B. and Nti, S. K. (2014). Teacher Education in Ghana: A Contemporary Synopsis and Matters Arising. SAGE. doi: 10.1177/2158244014529781

[15] Ayanful, R. (2016, June 20). Private schools call for government assistance. News Ghana. Retrieved 27th July, 2016 from https://www.newsghana.com.gh/private-schoolscall-for-government-assistance/

[16] Baidoo, P. K. (2015, October 28). Destroying the Ghanaian economy to provide free education. Ghana Web. Retrieved 18th August, 2016 from http://www.ghanaweb.co $\mathrm{m} /$ GhanaHomePage/features/Destroying-The-Ghanaian-Ec onomy-To-Provide-Free-Education-390129

[17] Boyle, H. N., Seebaway, S. Z., Lansah, I., \& Boukamhi, A. (2007). Islamic education sector study, Ghana. Education Development Centre, Inc. USAID/GHANA. Retrieved 13th November, 2015, from http://pdf.usaid.gov/pdf_docs/Pnadl 897.pdf 
[18] Braimah, A. I., Mbowura, C. K, \& Seidu, A. M. (2014). One state, two school systems: the instability of Ghana's school system since the fourth republic. Journal of Education and Practice, 5(9), 145. Retrieved 8th January, 2016, from http://iiste.org/Journals/index.php/JEP/article/download/11 $878 / 12227$

[19] Charnor, G. (2015, May 13). How Ghana can improve educational results for its poor children. Modern Ghana. Retrieved 27th July, 2016 from https://www.modernghana. com/news/617370/how-ghana-can-improve-educational-res ults-for-its-poor-child.html

[20] Cooper, C. W. (2009). Parent involvement, African American mothers, and the politics of educational care. Equity \& Excellence in Education, 42(4), 379-394.

[21] Cox, P. (2013, October 4). Low-fee private schools on the rise in Africa. Voice of America. Retrieved 27th July, 2016 from

http://www.voanews.com/content/low-fee-private-school-s on-the-rise-in-africa/1762924.html

[22] Creswell, J. W. (2013). Qualitative inquiry and research design: Choosing among five approaches (3rd ed.). Thousand Oaks, CA: Sage Publications, Inc.

[23] Creswell, J. (2009). Research design: Qualitative, quantitative, and mixed methods approaches. Thousand Oaks, CA: Sage Publications.

[24] Crozier, G., \& Davies, J. (2007). Hard to reach parents or hard to reach schools? A discussion of home-school relations, with particular reference to Bangladeshi and Pakistani parents. British Educational Research Journal, 33(3), 295-313.

[25] Danso, K. (2013, October 13). Ghana's educational system: Where did we go wrong? Ghana Web. Retrieved 14th October, 2014, from http://www.ghanaweb.com/GhanaHo mePage/NewsArchive/artikel.php?ID=288689

[26] Dewey, J. (1938). Experience and education. New York, NY: Simon \& Schuster.

[27] Denzin, N., Lynham, S., \& Guba, E. (2011). Paradigmatic controversies, contradictions, and emerging confluences, revisited. In N. Denzin \& Y. Lincoln (Eds.). The SAGE Handbook of Qualitative Research (4th ed.), 97-132.

[28] Earley, P., Bubb, S., Eddy-Spicer, D., Crawford, M., \& James, C. (2016). Governing bodies, headteacher performance and pay: the role of external advisers (Abstract). Educational Review. doi:10.1080/00131911.2016.1144560

[29] Eyiah, J. K. (2013, June 5). Fate of Ghana's education system: National agenda needed! Ghana web. Retrieved 14th October, 2014, from http://www.ghanaweb.com/GhanaHo mePage/NewsArchive/artikel.php?ID=275876

[30] Frankfort-Nachmias, C., \& Nachmias, D. (2008). Research methods in the social sciences (7th ed.). New York, NY: Worth Publishers.

[31] Ghana News Agency. (2015, June 23). Ghana urged to give needed importance to education. Retrieved 25th June, 2015, from

http://www.modernghana.com/news/625482/1/ghana-urged -to-give-needed-importance-to-education.html
[32] Ghana Statistical Service. (2012). 2010 population and housing census (PHC) final results. Ghana Statistical Service (GSS). Accra, Ghana: Author.

[33] Ghana Statistical Service. (2003). Core welfare indicators questionnaire. Accra: Government Publications.

[34] Godwyll, E. F. (2008). Education at the crossroads: The Ghanaian dilemma and puzzle. In G. Wan (Ed.). The Education of diverse student populations: A global perspective (pp. 111- 138). Dordrecht, Netherlands: Springer.

[35] Goodall, J., \& Montgomery, C. (2014). Parental involvement to parental engagement: A continuum. Educational Review, 66(4), 399-410. doi:10.1080/0013191 1.2013 .781576

[36] Gough, I., \& Wood, G. (2006). A comparative welfare regime approach to global social policy. World Development, 34(10). Retrieved 1st January, 2016, from http://eprints.lse.ac.uk/36646/1/ lse.ac.uk storage LIBRA RY_Secondary_libfile_shared_repository_Content_Gough, $\% 20$ I Gough comparative welfare regime 2006 Gough comparative_welfare_regime_2006.pdf

[37] Groves, M., \& Baumber, J. (2008). Regenerating schools: Leading the transformation of standards and services through community engagement. Bancyfelin, Carmarthen: Network Continuum Education

[38] HakiElimu. (2002). Tanzania education situation analysis. Dar es Salaam: HakiElimu.

[39] Hanson, A. E. (2012, July 23). Formal education in Ghana- a story of disappointment. Retrieved 14th October, 2014, from http://www.modernghana.com/news/407516/1/formal-educ ation-in-ghana-a-story-of-disappoinment.html

[40] Inkoom, A. (2012). Implementation of initiatives in Ghanaian education: The effect on rural Ghanaian junior high schools. Berlin: Lap Lambert Academic Publishing.

[41] Janesick, V. J. (2011). Stretching" exercises for qualitative researchers (3rd ed.). Thousand Oaks, CA: Sage.

[42] Kadingdi, S. (2006). Policy initiatives for change and innovation in basic education programmes in Ghana. Retrieved 22nd October, 2016 from http://educatejournal.or g/index.php/educate/article/viewFile/35/31

[43] Kallet, R. H. (2004). How to write the methods section of a research paper. Respiratory Care, 49(10), 1229-1232.

[44] Kim, Y. (2009). "Minority parental involvement and school barriers: Moving the focus away from deficiencies of parents." Educational Research Review, 4 (2), 80-102.

[45] Kocabas, I. (2009). The effects of sources of motivation on teachers' motivation levels. Education, 129(4), 724-742.

[46] Kothari, C. R. (2004). Research Methodology: Methods and Techniques (2nd ed.). New Age International (P) Ltd., Publishers. ISBN (13): 978-81- 224-2488-1.

[47] Kuyini, A. B., \& Mahama, F. K. (2014, November). Implementing child rights and protection law in Ghana: Case study (abstract). Retrieved 5th August, 2016 from http://www.challengingheights.org/wp-content/uploads/201 4/11/ImplementingChildRightsProtectionLawinGhana.2607 0718.pdf 
[48] Lamiell, P. (2012, November 2). How should politics influence education policy? Press Room: Policy. Retrieved 19th November, 2014, from http://www.tc.columbia.edu/ne ws.htm?articleID $=8381$

[49] Little, A. W. (2010, August). Access to basic education in Ghana: Politics, policies and progress. Retrieved 14th October, 2014, from http://www.createrpc.org/pdfdocument s/PTA42.pdf

[50] Ministry of Education. (2015). Basic education. Accra, Ghana: Ministry of Education.

[51] Ministry of Education. (2013). Ghana education reform 2007. Accra, Ghana: Ministry of Education.

[52] Ministry of Local Government and Rural Development. (2006). Ghana under Kwame Nkrumah: Social and economic developments. Ghana: Maks Publications \& Media Services.

[53] Mwin, D. O. (2016, June 8). Inclusive education policy in Ghana-addressing the varied learning needs of learners. Modern Ghana. Retrieved 20th July, 2016 from http://www.graphic.com.gh/features/opinion/inclusive-educ ation-policy-in-ghana-addressing-the-varied-learning-needs -of-learners.html

[54] Nordensvard, J. (2013). Using political metaphors to understand educational policy in developing countries: The case of Ghana and informal communities. Policy Futures in Education, 1(74). doi: 10.2304/pfie.2013.11.1.74 11.

[55] Ntim, S. (2014, July). The gap in reading and mathematics achievement between basic public schools and private schools in two administrative regions of Ghana: Where to look for the causes. American International Journal of Contemporary Research, 4(7), 109. Retrieved 6th January, 2016, from http://www.aijcrnet.com/journals/Vol_4_No_7_July_2014/ 14.pdf

[56] Obeng-Asamoa, P. K. (2016, June 6). Ghana's policy on inclusive education: A tool for national development. Ghana Web. Retrieved 20th July, 2016 from http://www.ghanaweb.com/GhanaHomePage/features/Ghan a-s-Policy-on-Inclusive-Education-A-tool-for-national-deve lopment-444807

[57] Olatunji, M. O. (2015, June). What is Nigeria's philosophy of education? American Journal of Social Sciences and Humanities, 5(2), 393-399. Retrieved 15th January 2016, from

http://www.ajsih.org/index.php/ajsih/article/view/189/168

[58] Osei, G. M. (2006). Teachers in Ghana: Issues of training, remuneration and effectiveness. International Journal of Educational Development, 26(1), 38-51.

[59] Osei-Owusu, B., \& Sam, F. K. (2012). Assessing the role of school management committees (SMCs) in improving quality teaching and learning in Ashanti Mampong municipal basic schools. Journal of Emerging Trends in Educational Research and Policy Studies, 3(5), 611-615.

[60] Patton, M. Q. (2002). Qualitative research and evaluation methods (3rd ed.). Thousand Oaks, CA: Sage Publications, Inc.

[61] Patton, M. Q. (1990). Qualitative evaluation and research methods (2nd ed.). Newbury Park, CA: Sage Publications.

[62] Paul, K., \& Emmanuel, M. (2014, August). Education and politics. Ghana Web. Retrieved 14th October, 2014, from http://www.ghanaweb.com/GhanaHomePage/features/artik el.php?ID=323052

[63] Pierce, A. (2013, April 23). Decentralization and social policy in Brazil: An analysis of health and education policies of the New Republic. Journal of International Affairs. Retrieved ${ }^{\text {rd }}$ August, 2016 from http://jia.sipa.columbia.ed $\mathrm{u} /$ online-articles/decentralization-and-social-policy-in-brazi

[64] Pinto, L. E. (2014). Learning through Civic participation: policy actors' perspectives on curriculum reform involvement in Ontario [Abstract]. Policy Features in Education, 12(3), 403-416. doi: 10.2304/pfie.2014.12.3.403

[65] Poku, J., Aawaar, G. M., \& Worae, T. A. (2013, June). Educational sector reforms in Ghana: a review. Global Research Journal of Education, 3(2), 20-31. Retrieved 18th January, 2016, from http:/www.globalresearchjournals.org/ fullarticles/51f8c1c87e6a1.pdfhttp://www.globalresearchjo urnals.org/journal/grje

[66] Sackey, H. A. (2008). Private Returns to Education in Ghana: Implications for Investments in Schooling and Migration. African Economic Research Consortium Research Paper 174: Nairobi, Kenya.https://www.issuelab.org/resources/21 816/21816.pdf

[67] Sarantakos, S. (1998). Social Research. (2nd ed.). London: Macmillan Press, Ltd.

[68] Senge, P. M. (2012). Creating schools for the future, not the past for all students. Leader to Leader. 65: 44-49. https://doi.org/10.1002/lt1.20035

[69] Siewobr, C. L. (2015). Government policies on the education front: My take. Modern Ghana. Retrieved 20th July, 2016 from

https://www.modernghana.com/news/624787/governmentpolicies-on-the-education-front-my-take.html

[70] Smith, D. K. (2000). From key stage 2 to key stage 3: Smoothing the transfer for pupils with learning difficulties. Tamworth: NASEN.

[71] Staff, K. (2016, May 30). History of education in Ghana. Retrieved 22nd October, 2016 fromnhttp://articles.ghanagri o.com/articles/ghana-history/26240-history-of-education-in -ghana.html

[72] Tagoe, M. (2011). Lifelong learning and the attainment of the education-related Millennium Development Goals 2 and 3 in Ghana: Is there a critical nexus? International Journal of Lifelong Education, 30(1), 19-35. doi: 10.1080/02601370.2 011.538191

[73] Thomas, P. L. (2012). Politics and education don't mix. Radical Scholarship. Retrieved 20th April, 2015, from http://wrestlingwithwriting.blogspot.com/search/label/politi cs

[74] Turney, K., \& Kao, G. (2009). Barriers to school involvement: are immigrant parents disadvantaged? Journal of Educational Research, 102 (4), 257- 271.

[75] Tyack, D., \& Cuban, L. (1995). Tinkering toward utopia: A century of public school reform. Cambridge: Harvard 
University Press.

[76] UNESCO. (2007). Education reform 2007 at a glance. Retrieved October 5, 2016 from http://www.unesco.org/education/edurights/media/docs/6ea 1d3dfbfe6402af81e83cf6031eaed279778f8.pdf

[77] UNICEF. (2012, April). All children in school by 2015: Global initiative on out-of-school children. Government of Ghana: UNICEF.

[78] Upper West Regional Education Office (2015). Education Management Information System (EMIS). Upper West Regional Office.
[79] Villines, S. (2014, August 3). What is policy? Retrieved 1st July, 2015, from http://www.sociocracy.info/what-is-a-poli cy/

[80] Wilder, S. (2014). Effects of parental involvement on academic achievement: A meta- synthesis. Educational Review, 66(3), 377-397. doi: 10.1080/00131911.2013.7800 09.

[81] Yusif, H. M., \& Yussof, I. (2010). A critical review of recent trends in basic and secondary schools enrolment in Ghana. Journal of Science and Technology, 30(1), 82-94 Retrieved 10th November, 2015, from http://www.ajol.info/index.php /just/article/download/53941/42488 